\title{
大気境界層観測レーダーによる風の観測 \\ Remote Sensing of Wind Velocity by Boundary Layer Radar
}

\begin{tabular}{|c|c|c|c|}
\hline \multirow{3}{*}{$\begin{array}{c}\text { 林田英俊 }{ }^{* 1} \\
\text { Hidetoshi HAYASHIDA }\end{array}$} & $\begin{array}{r}\text { 深尾昌一郎*2 }^{2} \\
\text { Syoichiro FUKAO }\end{array}$ & $\begin{array}{c}\text { 小林隆久*3 } \\
\text { Takahisa KOBAYASHI }\end{array}$ & $\begin{array}{c}\text { 韮沢 } \text { 浩*3 }^{* 3} \\
\text { Hiroshi NIRASAKA }\end{array}$ \\
\hline & $\nabla+\frac{1}{0}=1$ & 大竹和夫*1 & 苐湖雅う*1 \\
\hline & Yoshihiro MATAKI & Kazuo OHTAKE & Masayuki KIKUCHI \\
\hline
\end{tabular}

Recently, with an increase in the number of high-rise buildings, information about wind velocity at high altitudes has become more important. Boundary layer radar observations were carried out for about three months following completion of improvements in the observation system at the Meteorological Research Institute in Tsukuba. This paper shows the vertical profiles of wind velocity and a comparison with the results of wind profiler and high-rise tower observations. The results indicate that boundary layer radar can observe wind velocity up to an altitude of two to three kilometers and is of great use as a device for collecting wind data at high altitudes.

\section{1.はじめに}

建物の高層化に伴い、設計上支配的となる上空風の 風速、乱れの強さなどに関する情報の重要性が高まっ てきている。近年、音波を利用したりモートセンシン グ (ドップラーソーダ ) により、 $500 \mathrm{~m}$ 程度までの観測 が可能となり建築の耐風設計の観点からの観測も実施

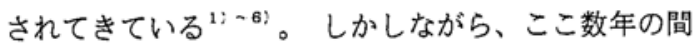
に高さ $600 \mathrm{~m}$ 以上の高層建築物の計画が次々と発表され、 より上空の風に関する情報が必要となってきた。今回、 つくばの気象研究所において上空 $2000 \mathrm{~m}$ 以上まで観測 可能な大気境界層観測レーダーを用いた風観測を実施 したのでその概要を報告する。本観測は、94年 1月よ り開始したがその後システムの変更・調整等を繰り返 してきた。本報では、システム変更完了後の 95 年12月 から96年 2月までの観測デー夕について報告する。

\section{2. 機器の概要}

大気境界層観測レーダーはLバンド（1.3GHz带）の ドップラーレーダーであり、大気の乱れを直接の散乱 体として風速の測定を行う。システムの主要諸元を表 -2.1に、機器の構成を図-2.1に示す。機器全体は空中 線装置、送受信演算装置、高速演算装置および信号処 理を行うパソコンから構成される。空中線装置は直径 $2 m$ のパラボラアンテナ 3 台からなり、それぞれ天頂お よび天頂から $15^{\circ}$ 北と東に傾けて設置されている（図 -2.2）。各アンテナより順次、送信・受信を繰り返す ことにより風速の 3 成分の鉛直分布を知ることができ る。基本的な原理はドップラーソーダの音波に代えて 電波を用いていると考えることができるが、電波の速 度が非常に高速であるため高い高度まで短時間でデー
表-2.1 大気境界層観測レーダーの主要諸元

\begin{tabular}{|c|c|c|}
\hline \multirow{2}{*}{\multicolumn{2}{|c|}{ 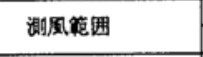 }} & 最高 $80 \mathrm{~m} / \mathrm{s} \quad$ (水平方向) \\
\hline & & 最高 $20 \mathrm{~m} / \mathrm{s} \quad$ （轻直方向） \\
\hline \multicolumn{2}{|c|}{ 测卑分艘能 } & FFTボイント数による \\
\hline \multicolumn{2}{|c|}{ 贯低高度 } & 䄪 $200 \mathrm{~m} \sim 300 \mathrm{~m}$ (固辺状況に上る) \\
\hline \multicolumn{2}{|c|}{ 取高敨庭 } & 約 $3,000 \mathrm{~m}$ (氮碀条件による) \\
\hline \multicolumn{2}{|c|}{ 高度分解能 } & $37.5 \mathrm{~m}$ \\
\hline \multicolumn{2}{|c|}{ 時间分舴能 } & 梧啭 約60秒 \\
\hline \multirow[t]{4}{*}{ フンテナ } & 形式 & 直径 2 mバラボラフンテナ：3台 \\
\hline & と-ム形状 & ペンシルヒーム \\
\hline & ビーム蟫 & $9^{\circ}$ 以下 \\
\hline & 利得 & $25 \mathrm{~dB}$ 以上 \\
\hline \multicolumn{2}{|l|}{ 周波数 } & $1357.5 \mathrm{MHz}$ \\
\hline \multicolumn{2}{|c|}{ 送信䆓力 } & $1 \mathrm{~kW}$ \\
\hline \multicolumn{2}{|c|}{ バルス焟 } & $0.67 \mu s$ \\
\hline \multicolumn{2}{|c|}{ パルス縟返し周波数 } & $20 \mathrm{kHz}$ \\
\hline \multicolumn{2}{|c|}{ 受信システは隻音指数 } & $3.5 \mathrm{~dB}$ 以下 \\
\hline
\end{tabular}

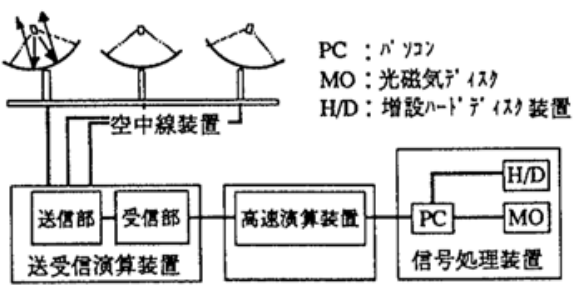

困-2.1 機器の構成

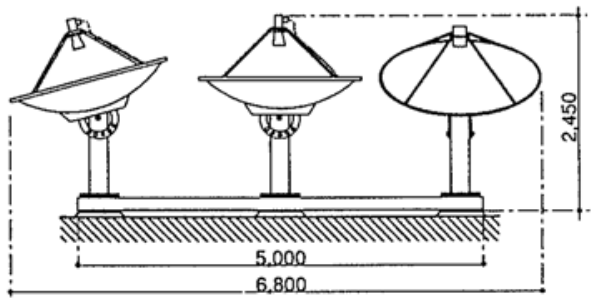

図-2.2 空中線装置外観図
*1 榎竹中工務店 技術研究所

*2 京都大学 超高尔需波研究センター教授

*3 気象研究所
Research \& Development Institute, Takenaka Corporation

(工博) Radio Atmospheric Science Center, Kyoto University Neteorological Research Institute 
夕を得ることができ、また、騒音の大きな悪天候にお ける測定も可能である。測定される風速は、電波ビー ム幅とパルス長により囲まれた円筒形空間（高さ500m では直径 $80 \mathrm{~m}$ 、長さ $200 \mathrm{~m}$ 程度となる）の平均的な風速 である(困-2.3)。標準的な測定モードでは37. $5 \mathrm{~m}$ 間隔 で高度約 $2900 \mathrm{~m}$ までの風速を 1 分間隔で収録する。

\section{3. 䚁測の概要}

境界層レーダー本体はつくばの気象研究所構内の気 象観測鉄塔の北側約 $200 \mathrm{~m}$ に設置しており、周囲は障害 物の少ない平坦地である。空中線装置およびその周囲 には周辺の固定物からの電波の反射（クラッター）を 防ぐため金属製のフェンスを設置している。

\section{4. 観測結果}

以下では、風速は水平成分のみを取り扱う。図-4.1 に観測結果の一例として96年 1月19日の17時から 1月 20日の 5 時および 2月17日の21時から 2月18日の 9時 における風速および風向の鉛直分布を、地上 $271 \mathrm{~m}$ から 2879m までの73高度について、後 述のウインドプロファイラーによ るデータとの比較のため、1 時間 平均値で示す。高度 $3000 \mathrm{~m}$ 近くま での風向・風速の連繶的な変化が 捉えられている。高さ $400 \mathrm{~m}$ 付近で 明らかに不連続なデータがみられ るが、現在のところはっきりした 原因は分かっていない。観測記録 より、高さによって風向が大きく 異なっていることがわかり、例え ば 1月19日の18時では高さ1000m 以下で風向は東北東であるのに対 し高さ2000m 以上ではほぼ反対の 南西となっている。また 2月17、 18日の記録では $1000 \mathrm{~m}$ 以下は北東 の風であるのに対し $2000 \mathrm{~m}$ 以上で

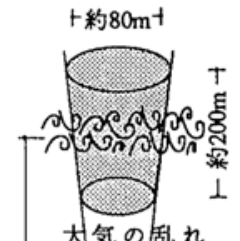

大気の乱 れ

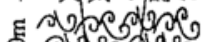

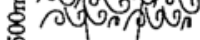

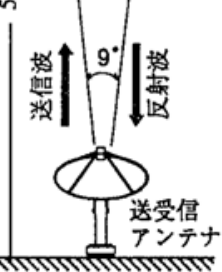

図-2.3 測定原理
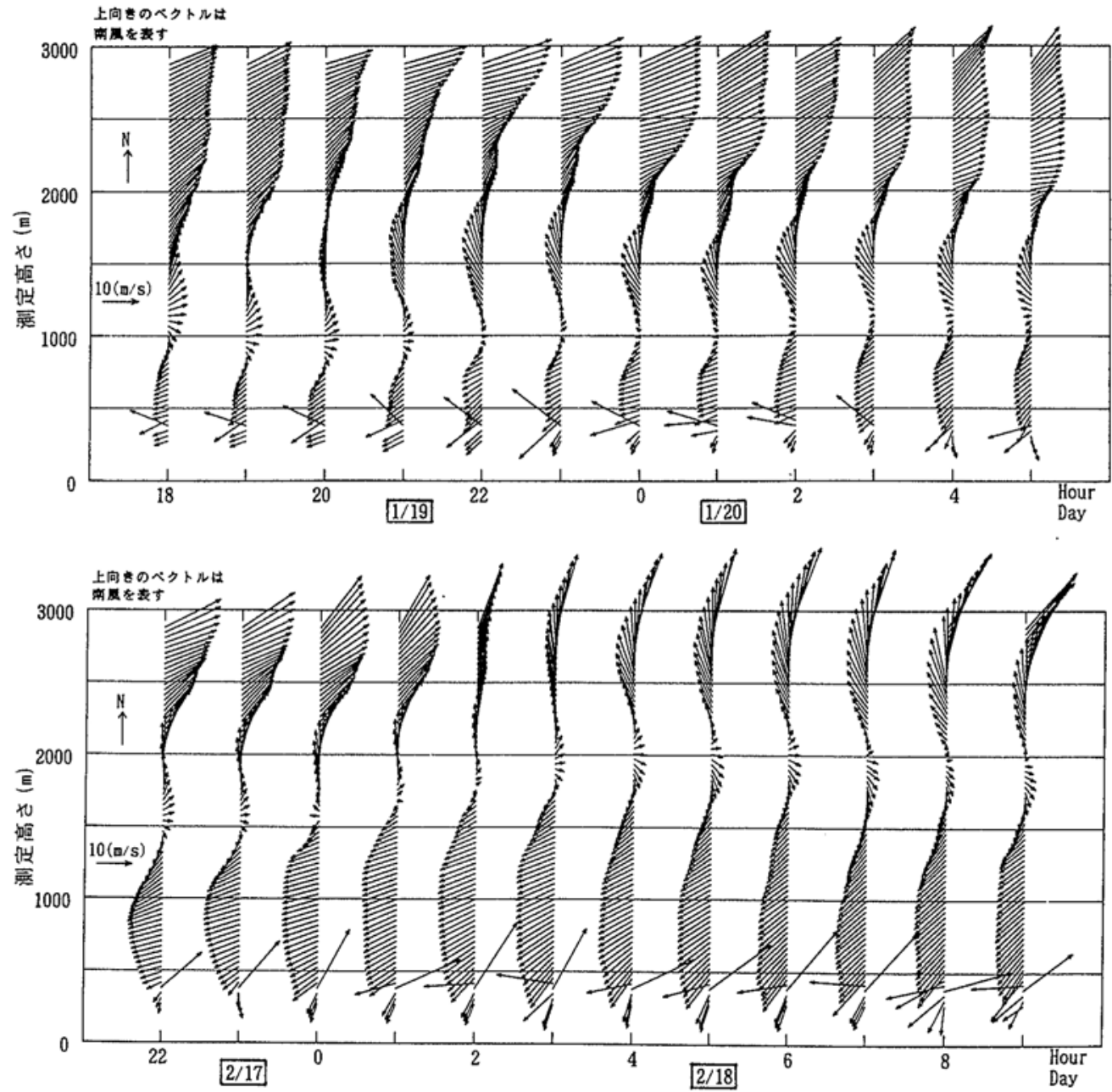

困-4.1 風速および風向の鉛直分布の時間変化 

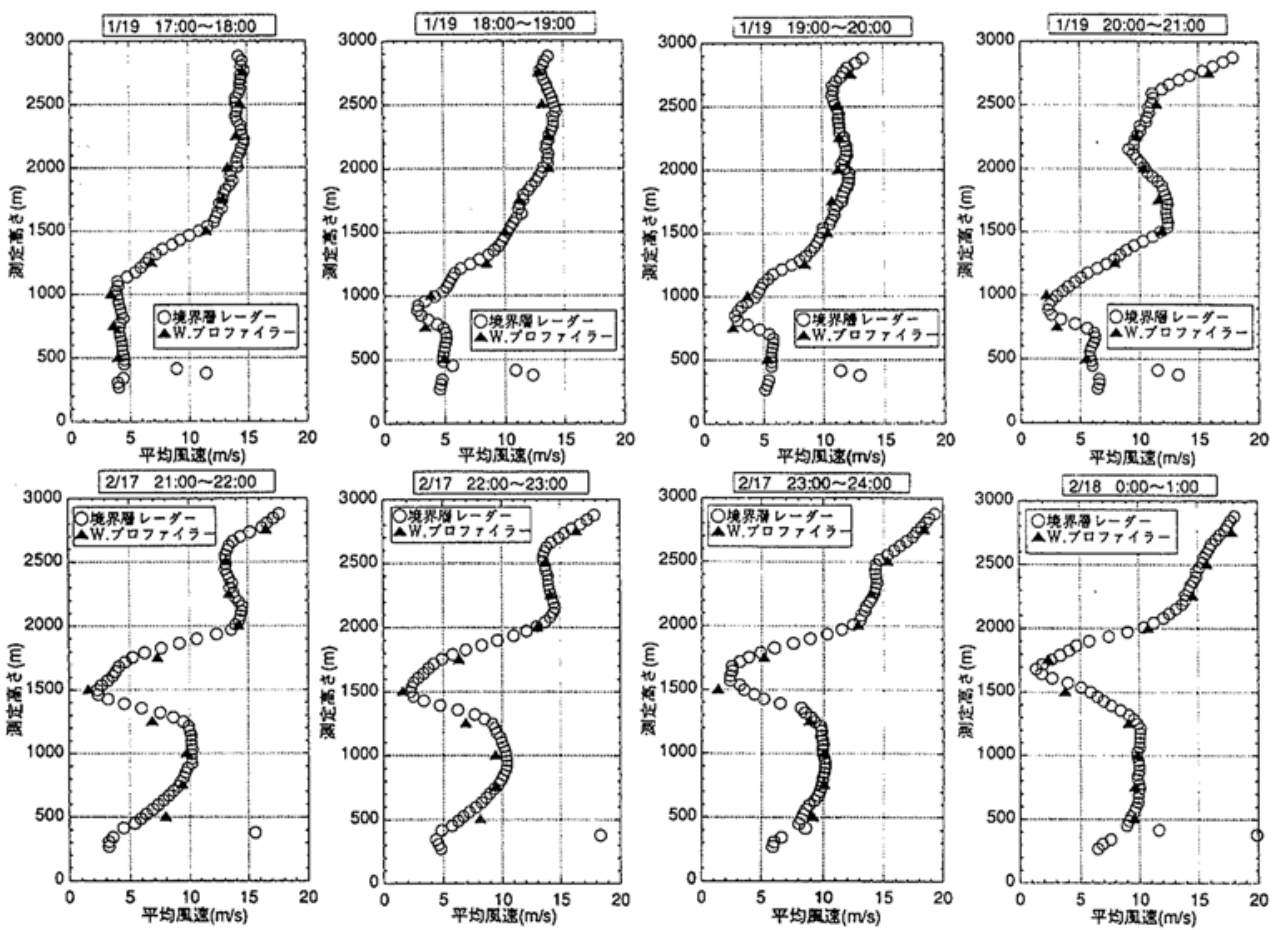

図-4.2 風速の鉛直分布
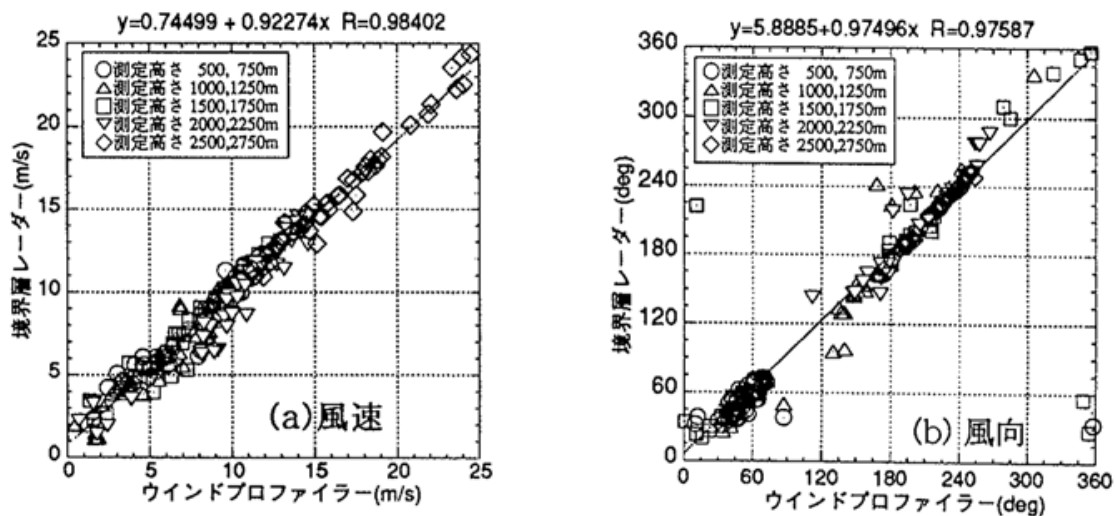

図-4.3 境界層レーダーとウインドプロファイラーの風速および風向の比較
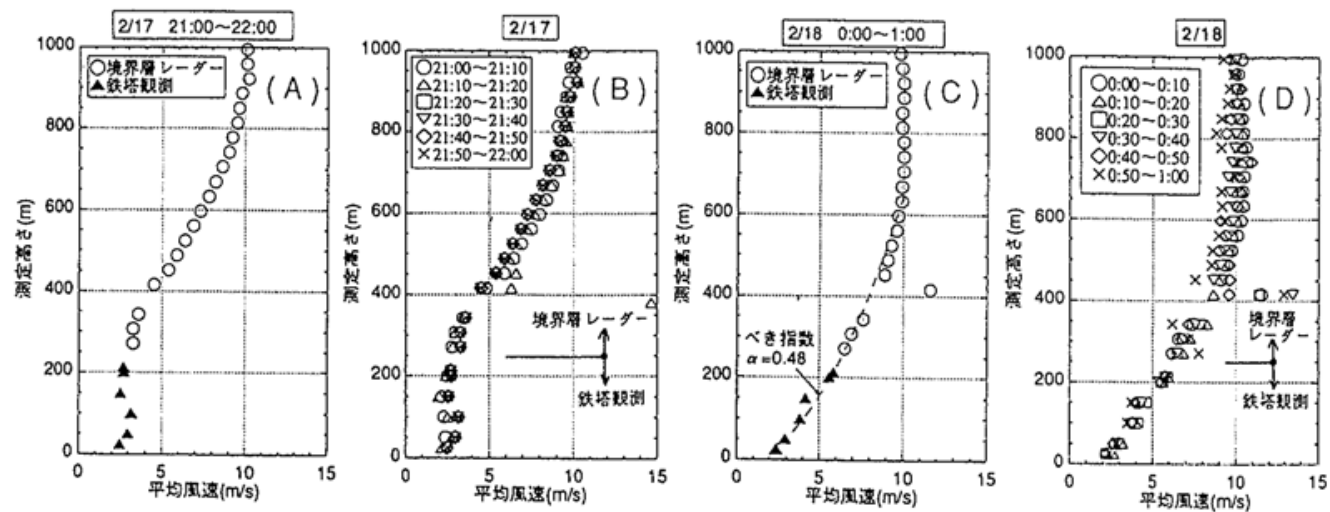

図-4.4 高さ1000m以下での風速の鉛直分布 
は2時頃を境にそれまで南西の風であったものが、南 東の風に変化している。図-4.2には、図-4.1の上、下 段に示した 1 時間平均風速の最初の 4 時間の風速の鉛 直分布を示す。17日21:00～22:00の記録のように、上 空にゆくにつれ、風速の增加と減少を何度か繰り返す ようなケースもみられる。図中には、気象研究所所有 の400MHz帯を用いたウインドプロファイラーによる風 速を併せて示しているが、本锶測値と良く一致してい る。困-4.3には同一時刻におけるウインドプロファイ ラーとの風速、風向の比較結果を示す。ウインドプロ ファイラーが、高さ500mから16kmを測定対象としてい るため 500 mか $52750 \mathrm{~m}$ まで、250m毎の10高度について 比較を行っている。結果より、風向に若干のばらつき があるものの風速、風向とも高い相関がみられる。本 レーターでは、これらの相関や図-4.2の風速の鉛直分 布より高さ 500 程度より高い高度においては安定した 測定値が得られている。次に観測可能な最低高度につ いて検討を行う。本境界層レーダーの理論的な測定可 能最低高度は、送信時間と送信から受信への切り替え 時間により決定され $200 \mathrm{~m} \sim 300 \mathrm{~m}$ となる。図-4.4に、高 さ1000m以下での風速の鉛直分布を示す。高さ $271 \mathrm{~m}$ 5996mまでの本観測値と併せて、気象研究所構内の鉄 塔锶測による高さ25、50、100、150、200 および213m での風速を示す。困中 $(\mathrm{A})(\mathrm{C})$ には 1 時間平均風速を (B) (D)には10分間平均風速を示す。評価時間の连い によらず風速は同様の分布傾向がみられ、いずれも本 観測值と鉄塔観測デー夕には連続性が認めれる。困一 4.4 に示す 2月17日、18日の記録は代表的な2つの分 布例であり、前者では風速は高さ $300 \mathrm{~m}$ 程度までは概ね 一定の值を示し、それより上空で高さとともに增加し ている。後者では、風速は地上から高さとともに增加 しており (C)において高さ633mまでのデータを用いて (400m付近の明らかに不連繶な風速は除く) べき指数 を求めると $\alpha=0.48$ となる。図-4.5には、境界層レ一 ダーの低高度の風速・風向デー夕（235mおよび271m） と気象観測鉄塔の高さ200mのデータの散布図を示す。 比較には鉄塔観測データの入手できた2月17日21時か ら18日9時までの 1 分間平均のデー夕を用いている。 風速の散布図の傾向は、概ね両高さとも一致しており デー夕は、ほほ０を通過し勾配が1より大きな回帰式 上に分布している。ただし、高度 $235 m$ では回帰式より 大きく外れるデータが增加し、相関係数も低下してい る。このデータのばらつきは、図-4.1に示した風速の ベクトル図でみると、ランタムムに発生しているのでは なく、18日の 7 時以降に集中して見られ、気象条件の 変化が影䪪していると考えられる。風向の散布図では、 比較に用いたデー夕の風向が限られていることもあり 相関係数が低く回㷌式も高さによってばらつく結果と
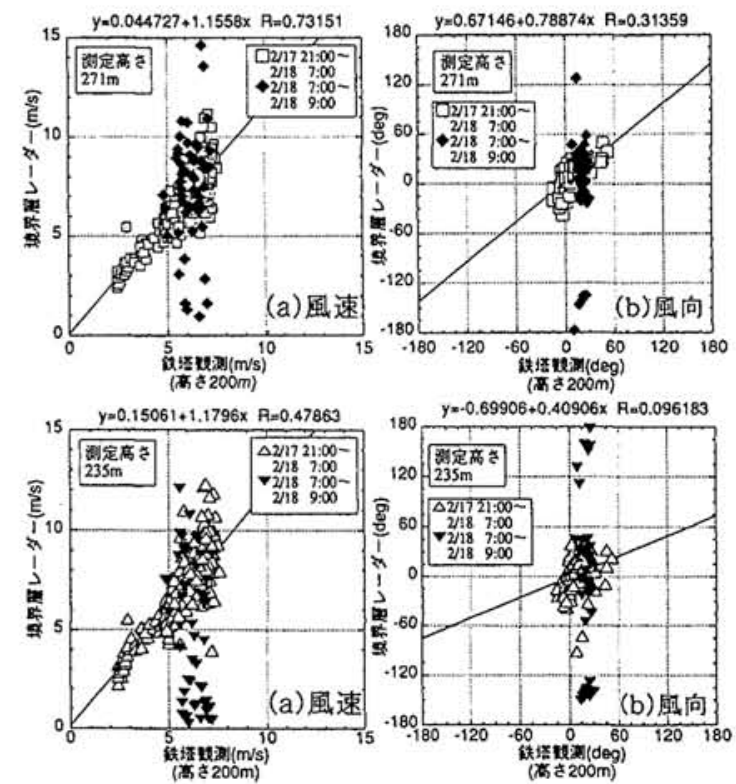

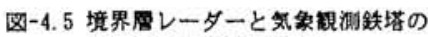
蛔速および庩向の比靶

なっているが、概ね鉄塔での風向と対応している。観 測データも少なく限られた検討ではあり、また、現状 では相関係数が低いケースも見られるが、本境界層レ 一ダーの観測可能な最低高度は、現在の状況では $250 \mathrm{~m}$ 前後と考えられる。ただし、信頼性のある観測記録と してデータを利用するためには大きく外れたデータを 除去するためのスクリーニング処理を実施する必要が ある。

\section{5.まとめ}

境界層レーダーによる気象研究所での観測結果を用 いて、風速、風向の鉛直分布の例を示し、ウインドプ ロファイラーによる観測および気象鉄塔観測との比較 を行った。本境界層レーダーによる風観測は、気象条 件によるものの高さ $250 \mathrm{~m}$ 程度から $2000 \mathrm{~m}$ 以上までの風 の情報収集に有効な手段であると考えられる。ただし 本報告で示した観測結果はいずれも降雪時のデータで あり、大気の乾燥した晴天時のデータに関しては、現 在のところデータの取得率が低下するケースが多い。 今後、更に観測を継続し晴天時のデー夕取得率の向上 をはかるとともに、データの信頼性を向上するための スクリーニング処理についても検討していきたい。

\footnotetext{
(

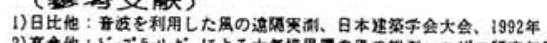

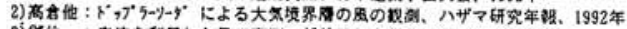

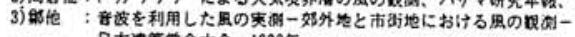
日太建策学会大会, 1993年

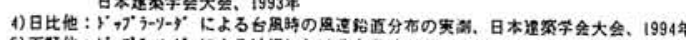

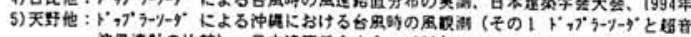

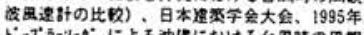

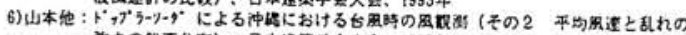

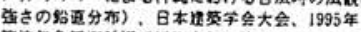

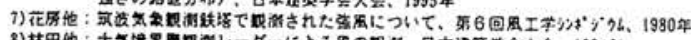

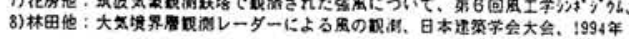

